\title{
The effect of land-use changes on the hydrological behaviour of Histic Andosols in south Ecuador
}

\author{
W. Buytaert, ${ }^{1,2 *}$ G. Wyseure, ${ }^{1}$ B. De Bièvre ${ }^{2}$ and J. Deckers ${ }^{1}$ \\ ${ }^{1}$ Laboratory for Soil and Water Management. Katholieke Universiteit Leuven. Vital Decosterstraat 102, 3000 Leuven, Belgium \\ ${ }^{2}$ Programa para el Manejo del Agua y del Suelo, Universidad de Cuenca, Cuenca, Ecuador
}

\begin{abstract}
:
The south Ecuadorian Andean mountain belt between 3500 and $4500 \mathrm{~m}$ altitude is covered by a highly endemic and fragile ecosystem called páramo. The Histic Andosols covering this region have highly developed hydric properties and exert a key function in the hydrological regulation of the páramo ecosystem. Unlike most Andosols, their extreme water retention capacity is not due to the presence of typical minerals such as allophane or imogolite. Although these minerals are virtually absent, the large organic carbon content, due to organometallic complexation, gives rise to similar properties. The water content at $1500 \mathrm{kPa}$ can exceed $2000 \mathrm{~g} \mathrm{~kg}^{-1}$, and the high hydraulic conductivity at saturation (about $15 \mathrm{~mm} \mathrm{~h}^{-1}$ ) drops sharply when low suction is applied. The three methods applied, i.e. the inverted auger hole, the tension infiltrometer and the constant-head permeameter method, give very similar results. The páramo is characterized by a slow hydrological response and a good water regulation, caused by the combination of a high water storage capacity and high conductivity. The wide pore size distribution of the organometallic complexes results in a water retention curve that differs significantly from the classic Mualem-Van Genuchten description, but can better be described with a simple linear or semilogarithmic model. The soils investigated are very prone to irreversible structural changes caused by land-use changes. The conversion of natural land for cultivation has a large impact on the hydrological function of the region. The water storage capacity increases by 5 to $30 \%$, and the hydraulic conductivity is $31 \%$ higher in cultivated catchments. These changes are related to a larger peak flow, a smaller base flow and generally a smaller discharge buffering capacity, despite the higher storage capacity. Copyright (c) 2005 John Wiley \& Sons, Ltd.
\end{abstract}

KEY WORDS páramo; Andosols; runoff response; infiltration; water retention; land-use changes; hydraulic conductivity

\section{INTRODUCTION}

\section{Land-use conflicts}

The páramo ecosystem is a neotropical alpine grassland extending from Colombia to northern Peru and covering the Andes region higher than 3500 m a.s.l. (Luteyn, 1992; Hofstede, 1995; Medina and Vásconez, 2001) (Figure 1). The interaction between the cold and wet highland climate and the volcanic ash deposits result in the formation of a peculiar upland peat soil with steep slopes, high amounts of organometallic complexes and special hydrophysical properties (Figure 2). The soil functions as a storage tank, releasing water in a slow hydrologic response. Water supply for drinking water, irrigation and hydro-electrical power relies heavily on the fairly constant source of high quality surface water coming from the páramo ecosystem.

In Ecuador, the páramo ecosystem has been a rather desolate area with little human activity except extensive cattle grazing. In recent years, farming land in the lower, more populated areas around Cuenca, Azogues and Cañar has been converted to urban areas, and the remaining farming land has severe problems with soil fertility loss and erosion (Dercon et al., 1998; Dercon, 2001). Farmers are moving upwards into the páramo, despite

* Correspondence to: W. Buytaert, Laboratory for Soil and Water Management, Katholieke Universiteit Leuven, Vital Decosterstraat 102 , 3000 Leuven, Belgium. E-mail: wouter.buytaert@agr.kuleuven.ac.be 


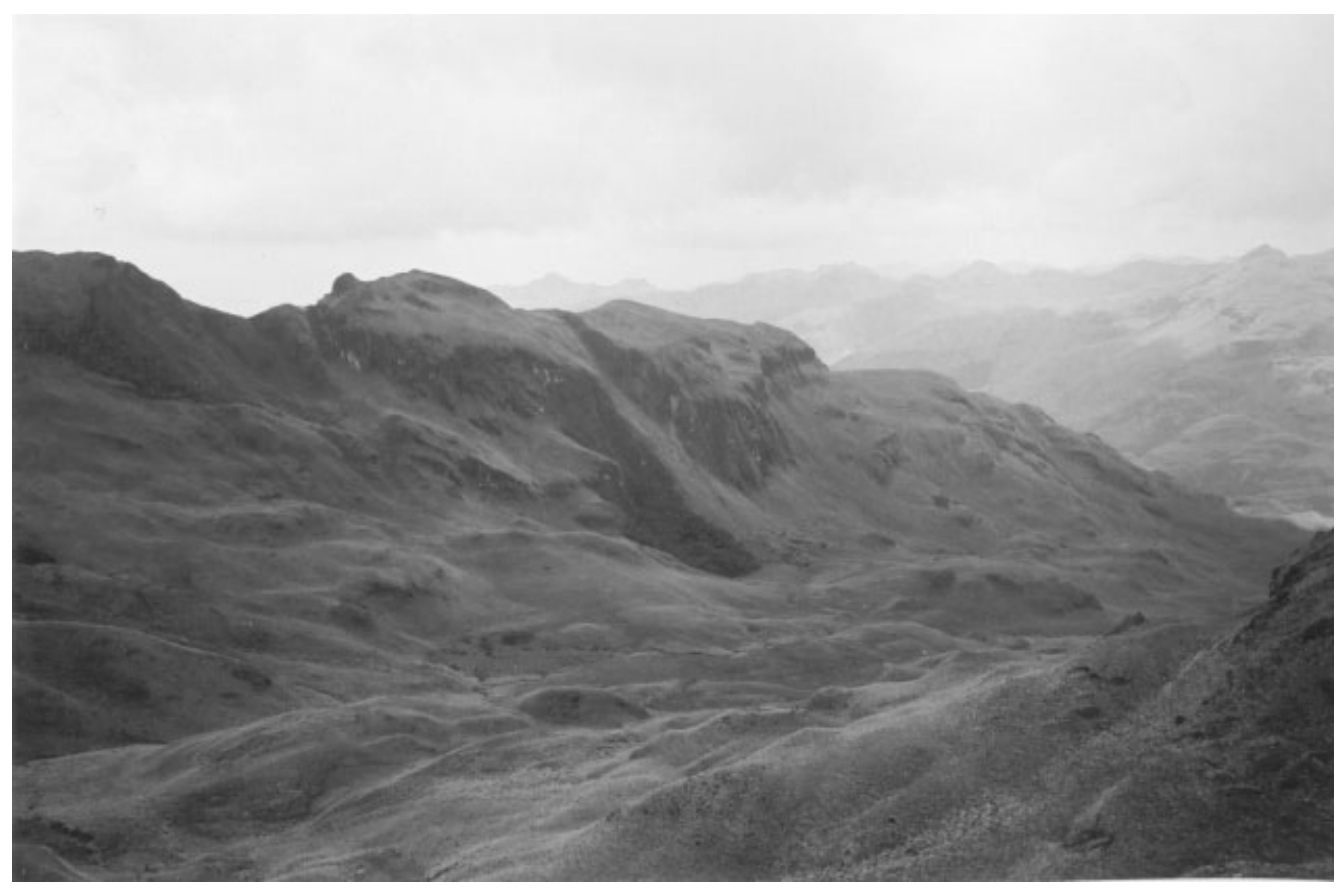

Figure 1. A typical view of the páramo ecosystem

the harsh weather, the difficult access and the unsuitable soils. Soils are drained and ploughed intensively to create more favourable cropping circumstances and to avoid waterlogging. Concerns have arisen with regard to the impact of these land-use changes on the reliability and availability of the páramo base flow streams. Local communities and organizations have reported a notable loss in water regulation capacity and base flow in páramo ecosystems that have been interfered with. The loss of regulation capacity in intensively grazed and cultivated páramo catchments in south Ecuador may reach a level of 40\% (Buytaert et al., 2004).

The mechanism responsible for the excellent water regulation capacity of the páramo is very poorly understood. Because of a predominance of grass species (Hedberg, 1992; Luteyn, 1992), water storage in the vegetation layer is minimal. Subsurface groundwater is nearly absent because of the presence of metamorphic bedrock. Hence, the hydrological behaviour is mainly determined by the soil. However, scientific literature about the hydrophysical properties of the páramo soils, as well as the impact of land-use changes on these properties, is very scarce. The soils combine the extremely high water retention capacity and high porosity of volcanic ash soils (Rousseaux and Warkentin, 1976; Nanzyo et al., 1993) with the high organic matter content and swell and shrink properties of peat soils (Holden and Burt, 2002, 2003), resulting in unique hydrophysical properties. This paper acts as a first step towards the understanding of the hydrological properties of páramo soils, and the impact of land-use changes thereon. This is done in three steps:

1. Determination of the water retention capacity and the hydraulic conductivity of páramo soils with low human impact. Three methods for the determination of the saturated hydraulic conductivity are used. These results are compared with the water content in the soil at field conditions and the discharge response of the catchments where the soil samples were taken.

2. Comparison of the water retention capacity and the hydraulic conductivity between extensively grazed soils and soils under intensive cultivation.

3. Fit the water retention curves to the Mualem-van Genuchten equation, to evaluate the physically based water retention model described by this equation for this soil type. 


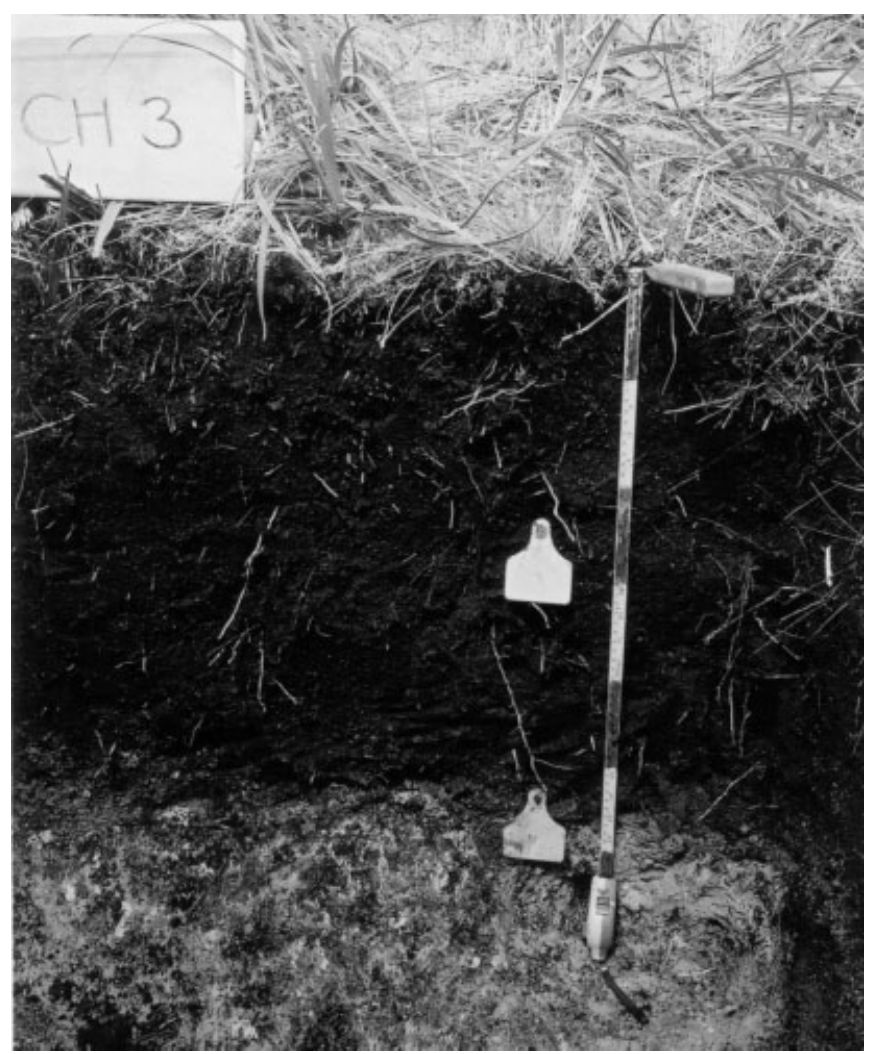

Figure 2. Histic Andosols in the páramo. A homogeneous, porous and strongly organic top horizon, about $0.7 \mathrm{~m}$ in depth, overlies a solid and impermeable bed rock

\section{Study region}

The study has been performed in the páramo of the Austro Ecuatoriano, the southern Ecuadorian Andes region between $2^{\circ} 15^{\prime}$ and $3^{\circ} 0^{\prime}$ latitude south (Dercon et al., 1998). Vegetation consists of small grass species and scarcely scattered patches of quinoa trees (Hedberg, 1992; Luteyn, 1992). The south Ecuadorian páramo has a udic climate regime (Van Wambeke, 1981) and an isomeric temperature regime. Rainfall is rather high and well distributed in time, averaging between 1200 and $1600 \mathrm{~mm} \mathrm{year}^{-1}$. Frequent fog and drizzle add an unknown quantity of water compared with the rain-gauge observations. Mean annual temperature is around $7{ }^{\circ} \mathrm{C}$ and is rather constant over the year, but shows high day-night variation: the average daily maximum is $13.2^{\circ} \mathrm{C}$ and the average daily minimum is $4.6^{\circ} \mathrm{C}$ (Buytaert, 2004). Snowfall occurs rarely and is not significant.

Unlike their high organic matter content, the soils of the páramo differ significantly from regular peat soils, due to their stronger soil structure. They have a low bulk density of around $0.3 \mathrm{Mg} \mathrm{m}^{-3}$, a high organic carbon content between 100 and $400 \mathrm{~g} \mathrm{~kg}^{-1}$ and a predominance of organometallic complexes (Buytaert, 2004). Breakdown of volcanic ash deposits results in a high content of aluminium, iron and amorphous minerals. Therefore, the soils are classified as Andosols according to FAO/ISRIC/ISSS (1998).

\section{Andosol vulnerability}

The vulnerability of Andosols is well documented in the literature. In natural conditions, they have an open structure with good rootability and good aeration, which is prone to irreversible changes and degradation 
(Dorel et al., 2000). Irreversible volume change, lowering of water retention and increases in hydraulic conductivity and hydrodynamic dispersion after drying and rewetting are reported (Wada, 1985; Nanzyo et al., 1993; Basile and De Mascellis, 1999). Most of these changes also occur due to cultivation (Poulenard et al., 2001; Buytaert et al., 2002). Further problems related to Andosol cultivation are erosion (Neall, 1985), crust formation (De Noni et al., 2000), lower organic matter content and a decrease in soil moisture (Higuchi and Kashiwaga, 1993; Moroizumi and Horino, 2002). Other reported changes in hydrodynamic behaviour are increasing surface runoff, decreasing infiltration (Neall, 1985), development of larger pores and of preferential flow paths, and a decrease of the terrain roughness (Basile and De Mascellis, 1999; Poulenard et al., 2001). A major problem in the Andean region is frequent burning of the vegetation, which may induce increased surface runoff by forming hydrophobic and stable soil aggregates with high water repellency (Wada, 1985; Valat et al., 1991; Golchin et al., 1997; Piccolo and Mbagwu, 1999; Poulenard et al., 2001).

\section{MATERIALS AND METHODS}

\section{Site selection and sampling}

Selection of study sites in the Austro Ecuatoriano is difficult, due to highly dynamic land use and the lack of historical data.

The study was done at three locations: Huagrauma, Soroche and Queseras (Figure 3). Huagrauma and Soroche are located in the Machangara basin at a distance of $3 \mathrm{~km}$ from each other. The Huagrauma catchment $\left(2.5 \mathrm{~km}^{2}\right)$ has a low human impact, and only extensive grazing takes place. It is representative for the 'natural'

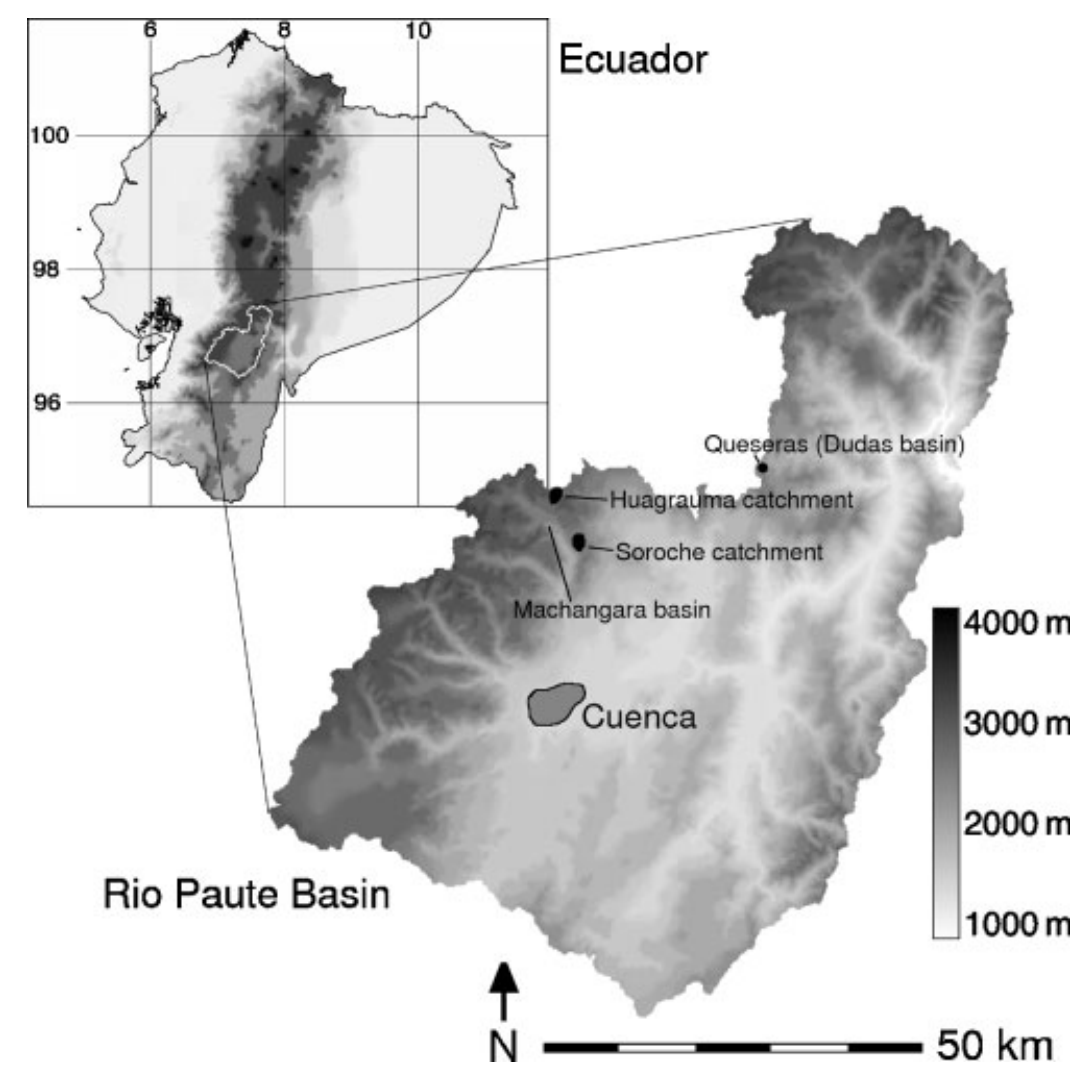

Figure 3. Location of the experimental catchments in the Rio Paute basin, Ecuador. Coordinates are in $10^{5}$ UTM 
páramo in the region, because very few locations exist where the traditional grazing practices do not occur. On the other hand, the Soroche catchment is heavily disturbed by artificial drainage and cultivation. A part of the catchment is used for the cultivation of potatoes, while in the other part the original grass vegetation has been replaced by more nutritious species that are intensively grazed. The catchments where selected for their easy access, their known land-use history, and the representativeness of the human activities for the region. However, differences in soil properties between the locations may be due to geographical differences and not due to land-use differences. Therefore, Queseras was selected as a secondary experimental location. In this catchment (about $100 \mathrm{~km}^{2}$ ), cultivated fields are patched in between vegetation. This location has the advantage that samples under cultivated fields can be taken side by side with samples under natural vegetation, reducing the impact of geographic variation. However, land use is highly dynamic in this region; thus, the samples taken under natural land may not be considered representative for the natural páramo and the results from this site are only used to compare different land uses.

In both Chanlud and Soroche, three soil profiles were described at the west-facing slope between 3400 and $3500 \mathrm{~m}$ altitude. In each profile, 12 undisturbed samples were taken in $100 \mathrm{~cm}^{3}$ steel rings, and about $1 \mathrm{~kg}$ of soil was collected in each of the three soil horizons.

In Queseras, 40 undisturbed samples were taken in $100 \mathrm{~cm}^{3}$ steel rings, at $15 \mathrm{~cm}$ depth. Therefore, five sites below cultivated fields and five sites of natural grassland sites were randomly selected, evenly distributed over the catchment. At the same sites, about $1 \mathrm{~kg}$ of soil was collected.

\section{Sample analysis}

Different methods are available for the determination of the saturated hydraulic conductivity of soils. In this study, the constant-head permeameter was used (Brady and Weil, 1999). In this laboratory technique, undisturbed soil samples, after saturation, are subjected to a slight hydraulic overpressure. The saturated hydraulic conductivity is derived solving the Darcy equation towards the conductivity term:

$$
K_{\mathrm{s}}=\frac{V l}{(l+d) t A}
$$

where $K_{s}\left(\mathrm{~mm} \mathrm{~h}^{-1}\right)$ is saturated hydraulic conductivity, $V$ the water volume flowing through the section $A\left(\mathrm{~mm}^{2}\right), t(\mathrm{~h})$ the time, $l(\mathrm{~mm})$ the soil sample height and $d(\mathrm{~mm})$ the water head height. This method was chosen because the procedure is fast and straightforward and can be done in laboratory conditions, and the sample collection time in the field is limited, which is important in a remote and inaccessible area such as the páramo. Nevertheless, the major disadvantages of this method are a small sample volume, a one-dimensional conductivity and a risk of disturbance of the soil structure during sampling. Therefore, 24 additional measurements were done with both the inverted auger hole method and the tension infiltrometer. The auger hole test above the water table, referred to as the inverted auger hole test, consists of boring a hole to a given depth, filling it with water, and measuring the rate of fall of the water level. If the soil is saturated, then the hydraulic gradient can be supposed to be equal to unity. From a combination of a mass balance equation and Darcy's law, the saturated hydraulic conductivity can be calculated as

$$
K_{\mathrm{s}}=1 \cdot 15 r s
$$

where $K_{\mathrm{s}}\left(\mathrm{cm} \mathrm{h}^{-1}\right)$ is the saturated hydraulic conductivity, $r(\mathrm{~cm})$ is the radius of the auger hole, $s$ the slope of the line $\log (h+r / 2)$ versus time and $h$ is the height of water column in the auger hole. Contrary to the constant-head permeameter method, where samples were taken vertically, the measured values of the inverted auger hole correspond largely to the horizontal saturated hydraulic conductivity (Ritzema, 1994). While avoiding the disadvantages of the constant-head permeameter method, this method is prone to a $K_{\mathrm{s}}$ gradient over depth, as well as the occurrence of cracks and preferential flow paths. In order to determine the hydraulic conductivity at higher suction heads, 10 tension infiltrometer experiments were undertaken, at 
suction heads of 3 and $15 \mathrm{~cm}$ (Clothier et al., 1992). Here, saturated hydraulic conductivity can be calculated by the equation given by Logsdon and Jaynes (1993):

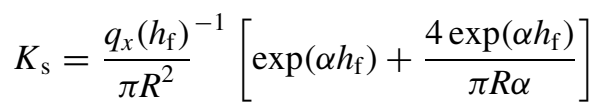

where $q_{x}\left(\mathrm{~mm} \mathrm{~h}^{-1}\right)$ is the steady-state infiltration rate at a certain suction head $h_{f}(\mathrm{~cm}), \pi R^{2}\left(\mathrm{~mm}^{2}\right)$ is the disc area, $K_{\mathrm{s}}\left(\mathrm{mm} \mathrm{h}^{-1}\right)$ is the saturated hydraulic conductivity, and $\alpha$ is an unknown constant (iterative solution). Given the limitations of the application of the tension infiltrometer method in peaty soils (Holden et al., 2001) and the small amount of samples, interpretation of these results should be done with care.

After determination of the saturated hydraulic conductivity with the constant-head permeameter method, the water retention of the steel-ring samples was established with the multistep outflow method (Inoue et al., 1998) at $0,-20$ and $-50 \mathrm{kPa}$ pressure. Afterwards, bulk density was determined after drying the samples for $24 \mathrm{~h}$ at $105^{\circ} \mathrm{C}$. Water retention at -300 and $-1500 \mathrm{kPa}$ was established separately with the collected soil using a porous membrane pressure cell. A $\mathrm{pF}$ value of 5.9 was obtained by determining the water retained in soil samples air-dried in laboratory conditions.

The water retention curve was modelled with the Mualem-Van Genuchten model (Mualem, 1976; Van Genuchten, 1978) based on the outflow data from the multistep experiment. The Mualem-Van Genuchten equation describes the water retention curve $h$ as

$$
h\left(S_{\mathrm{e}}\right)=\frac{\left(S_{\mathrm{e}}^{-1 / m}-1\right)^{1 / n}}{a}
$$

where the effective saturation $S_{\mathrm{e}}=\left(\theta-\theta_{\mathrm{r}}\right) /\left(\theta_{\mathrm{s}}-\theta_{\mathrm{r}}\right), m=1-1 / n, a, n$ and $l$ are empirical parameters, $\theta_{\mathrm{r}}$ and $\theta_{\mathrm{s}}$ are respectively the residual and saturated water contents, and $K_{\mathrm{S}}$ is the saturated hydraulic conductivity. Optimization was done using Marquardt's method, as described by Van Dam et al. (1992).

For the determination of the actual water content of the páramo soils, 56 soil samples were taken at the experimental site in the Huagrauma catchment in six time steps from September to December 2001. The samples were taken in $100 \mathrm{~cm}^{3}$ steel rings and the water content was determined gravimetrically based on the weight after drying for $24 \mathrm{~h}$ at $105^{\circ} \mathrm{C}$.

Discharge was calculated from water level monitoring at 15 min intervals in a V-notch from August 2001 to December 2003. Rainfall was registered over the same time period with three tipping-bucket rain gauges at a resolution of $0.2 \mathrm{~mm}$.

\section{RESULTS AND DISCUSSION}

\section{Water retention capacity}

Figure 4 shows the volumetric water retention capacity of the soil. The extremely high water retention of Andosols (up to 95 vol.\% at saturation) has been described by various workers (Rousseaux and Warkentin, 1976; Shoji and Fujiwara, 1984; Nanzyo et al., 1993) and is mostly attributed to the presence of amorphous clay minerals such as allophane and imogolite. Earlier studies on páramo soils (Poulenard et al., 2001; Buytaert, 2004) indicate that short-range order minerals are nearly absent in the south Ecuadorian Andosols, as aluminium and iron released by volcanic ash breakdown are completely bound to organic matter. The organic carbon accumulation, due to the cold and wet climate and organometallic complexation, gives rise to a similar behaviour, given the high correlation between organic carbon content and water retention at various pressure heads (Figure 5). The $1500 \mathrm{kPa}$ water content, and thus the amount of micropores, is highly affected by the amount of organic carbon. As a result, organic colloids are very important in the microporosity development of the Andosols described. The increase in volume of micropores $(>2 \mu \mathrm{m})$ due to organic carbon is around $4.1 \mathrm{ml} \mathrm{g}^{-1}$ (Figure 5). This value is higher than found in most soil types $\left(0-3 \mathrm{ml} \mathrm{g}^{-1}\right.$; Brady and Weil, 1999), 


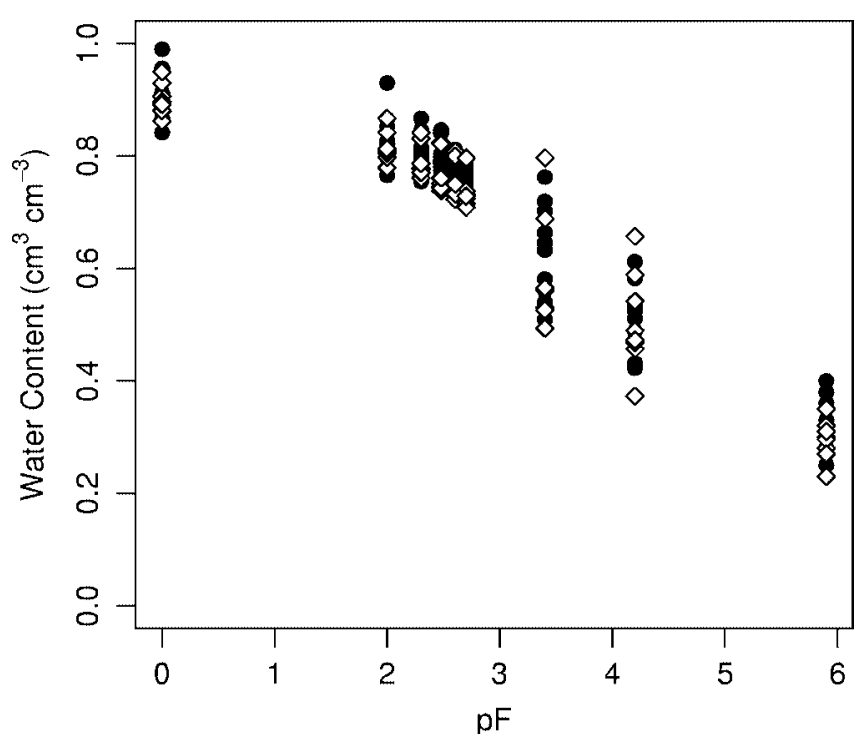

Figure 4. Volumetric water retention curves measured with the multistep outflow method, porous membrane (pF 3.4 and 4.2$)$ and air-dry moisture (pF 5.9). •: Soroche catchment, $\diamond:$ Huagrauma catchment

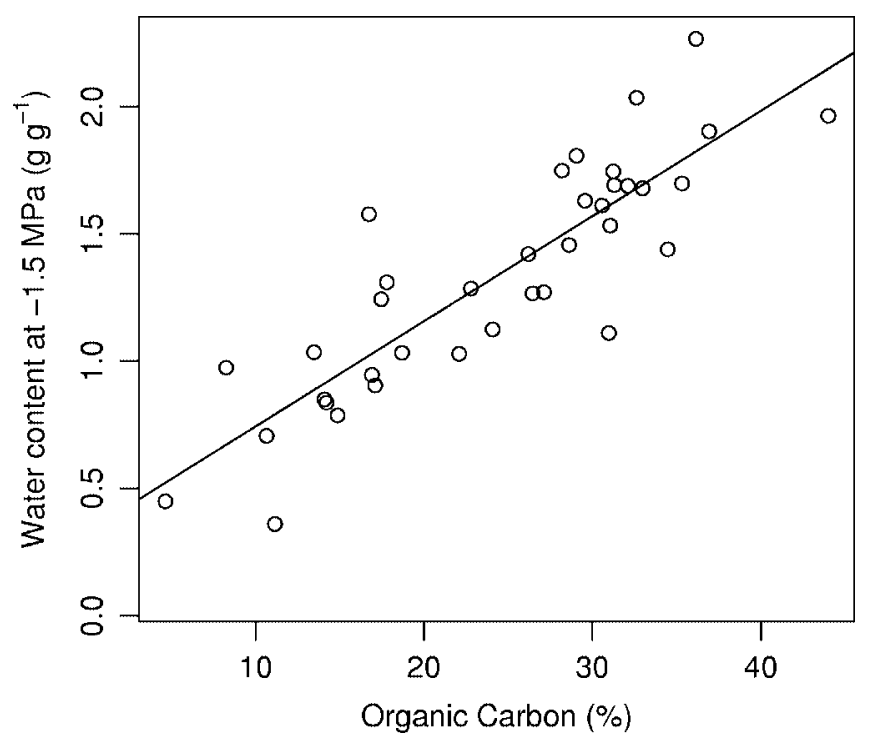

Figure 5. Correlation between the organic carbon content of the soils and the water retention at $-1500 \mathrm{kPa} . R^{2}=0 \cdot 75$

but lower than the value of $7.5 \mathrm{ml} \mathrm{g}^{-1}$ calculated by Poulenard et al. (2001) for north Ecuadorian páramo soils.

\section{Hydraulic conductivity}

The average values for the saturated hydraulic conductivity determined by the constant-head permeameter, the inverted auger hole method and the tension infiltrometer method are respectively $14.6 \mathrm{~mm} \mathrm{~h}^{-1}$, $17.1 \mathrm{~mm} \mathrm{~h}^{-1}$ and $11.7 \mathrm{~mm} \mathrm{~h}^{-1}$ (Figure 6). Thus, both the average values of the different methods and the 


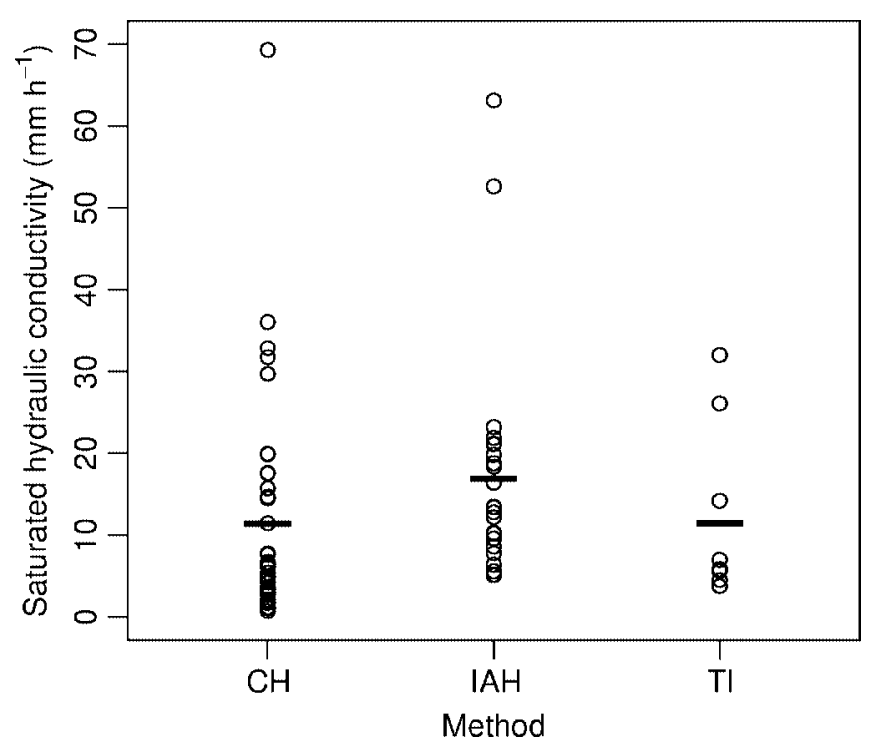

Figure 6. Comparison of different methods to measure saturated conductivity. $\mathrm{CH}$ : constant-head impermeameter; IAH: inverted auger hole; TI: tension infiltrometer; bars indicate arithmetic means

range of the data are close together. This most probably indicates that the representative elementary volume (REV) of páramo soils is close to the volume of the $\left(100 \mathrm{~cm}^{3}\right)$ steel-ring samples. The REV is defined as the smallest adequate sampling volume for characterizing the actual structure (Bear, 1972). In a small sample volume, the larger pores, or macropores, which are critical for the saturated hydraulic conductivity of the soil, may occur less frequently and may be less well represented, leading to an underestimation of the hydraulic conductivity. On the other hand, if present in the core sample, macropores may contribute more to the flow than they actually do in the field, where they are discontinuous as dead-end large pores (Bouma, 1982). Both mechanisms induce a large variance and errors in the results, which is less likely to occur in large samples. In a similar study on Vertic Luvisols in the Austro Ecuatoriano, the average saturated hydraulic conductivity measured by the inverted auger hole method was 27 times larger than the average value obtained by the constant-head method (De Bièvre, 2002). In this soil type, contrary to the Andosols studied, the REV is probably larger than the samples used for the constant-head method $\left(100 \mathrm{~cm}^{3}\right)$. It may be concluded that in the páramo soils studied, the spatial variability of the pores is low, as small samples are quite representative. Also, owing to the large porosity of the soils, the amount of dead-end pores may be limited.

Finally, the mean hydraulic conductivity at -3 and $-15 \mathrm{~cm}$ pressure heads, measured with the tension infiltrometer method, shows a dramatic decrease, from $5.3 \mathrm{~mm} \mathrm{~h}^{-1}(-3 \mathrm{~cm})$ to $0.52 \mathrm{~mm} \mathrm{~h}^{-1}$ at $-15 \mathrm{~cm}$.

\section{Páramo hydrology}

The high water-regulation capacity of the páramo, having almost mythical recognition among farmers, is confirmed by analysis of the discharge data of Huagrauma, the catchment with low human impact. The lowest discharge is registered in the period from September to November 2001 (Figure 7). This period was exceptionally dry for the Austro Ecuatoriano páramo, with only $73 \mathrm{~mm}$ of rainfall in 2 months, compared with a mean of $117 \mathrm{~mm}$ month $^{-1}$ over the examined 2-year period. During this time, the base flow always remains above $0.8 \mathrm{~mm} \mathrm{day}^{-1}$. The registration of the actual water content of the soil in Huagrauma was measured in the same period (Figure 7). No general reduction in water content is observed at the study site. The lowest average water content registered $\left(0.67 \mathrm{~cm}^{3} \mathrm{~cm}^{-3}\right)$ even occurs at the beginning of this period (4 September 2001). Nevertheless, the actual water content varies considerably, between 0.83 and $0.67 \mathrm{~cm}^{3} \mathrm{~cm}^{-3}$, which 


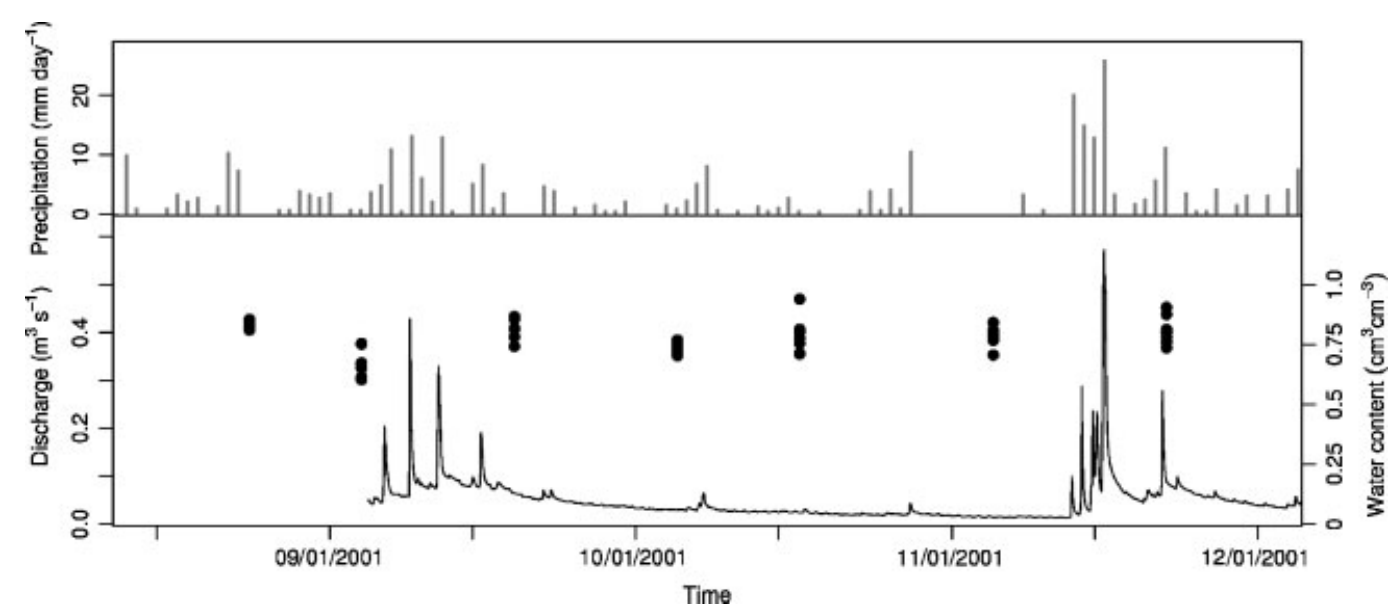

Figure 7. The actual water content of the soils of the Huagrauma catchment over time, compared with the rainfall and discharge in the catchment for a selected period

corresponds to the $\mathrm{pF}$ range between 2 and 3.2 in Figure 4 . This amounts to a storage capacity of at least $130 \mathrm{~mm}$, for an average soil depth of $0.8 \mathrm{~m}$ (Buytaert, 2004).

The high temporal variation in water content, as well as the high base flow, contrasts with the low unsaturated hydraulic conductivity of the soils $\left(0.52 \mathrm{~mm} \mathrm{~h}^{-1}\right.$ at $\left.-15 \mathrm{~cm}\right)$. Possible mechanisms are: (1) the existence of a dense natural drainage network, resulting in a small average drain distance that compensates for the low unsaturated hydraulic conductivity; (2) water regulation dominated by swamps in the flat areas at the valley bottom, where saturated conditions and ponding occur almost continuously. At this time, no definitive conclusions can be drawn, as research concerning these processes in the páramo is very limited.

\section{Land-use impacts}

Poulenard et al. (2001), Buytaert et al. (2002, 2004) and Podwojewski et al. (2003) have demonstrated that land-use changes have an important effect on the hydrological behaviour of the soil and especially on the base flow of the rivers. Differences in water retention and the total available water content (pF 2.4-4.2) between Huagrauma and Soroche, as well as between the different land-use types of Queseras, were statistically tested using the Mann-Whitney $U$ test (Table I) and Student's $t$-test (Table II). In Huagrauma and Soroche, the difference in saturated hydraulic conductivity was also tested.

The average total available water content is slightly larger in the cultivated Soroche catchment compared with Huagrauma (Table I). However, the differences are extremely small $\left(5 \%\right.$, or $\left.0.03 \mathrm{~cm}^{3} \mathrm{~cm}^{-3}\right)$ and not significant. A similar tendency is observed in Queseras, but here the difference is larger and significant: $32 \%$, or $0.10 \mathrm{~cm}^{3} \mathrm{~cm}^{-3}$. The difference is due to a significantly lower water retention at $\mathrm{pF} 4.2$, as the water

Table I. Average water content $\left(\mathrm{cm}^{3} \mathrm{~cm}^{-3}\right)$ at different pressures, and saturated hydraulic conductivity $\left(\mathrm{mm} \mathrm{h}^{-1}\right)$ of the natural Huagrauma and the cultivated Soroche catchment. $P$ indicates the chance of equal means between the two catchments. $\mathrm{P}$ values in bold are significant at 0.05 level

\begin{tabular}{lcccccccrr}
\hline & $\mathrm{pF} 0$ & $\mathrm{pF} 2$ & $\mathrm{pF} 2.3$ & $\mathrm{pF} 2.5$ & $\mathrm{pF} 2.7$ & $\mathrm{pF} \mathrm{3.4}$ & $\mathrm{pF} \mathrm{4.2}$ & $\mathrm{TAW}^{\mathrm{a}}$ & $K_{s}$ \\
\hline Cultivation & 0.91 & 0.83 & 0.81 & 0.79 & 0.76 & 0.61 & 0.49 & 0.31 & 17.51 \\
Natural & 0.90 & 0.81 & 0.79 & 0.77 & 0.74 & 0.58 & 0.50 & 0.28 & 12.05 \\
$P$ & 0.63 & 0.35 & 0.32 & 0.12 & 0.18 & 0.36 & 0.99 & 0.90 & $\mathbf{0 \cdot 0 4}$ \\
\hline
\end{tabular}

a Total available water content. 
Table II. Average water content $\left(\mathrm{cm}^{3} \mathrm{~cm}^{-3}\right)$ at different pressures of soil samples under both natural land and cultivation, in the region of Queseras. $P$ indicates the chance of equal means. $\mathrm{P}$ values in bold are significant at 0.05 level

\begin{tabular}{lccccc}
\hline & $\mathrm{pF} 0$ & $\mathrm{pF} 2 \cdot 3$ & $\mathrm{pF} 2 \cdot 7$ & $\mathrm{pF} 4 \cdot 2$ & TAW $^{\mathrm{a}}$ \\
\hline Cultivation & 0.73 & 0.65 & 0.65 & 0.34 & 0.31 \\
Natural & 0.73 & 0.64 & 0.63 & 0.42 & 0.21 \\
$P$ & 0.90 & 0.50 & 0.37 & $\mathbf{0 \cdot 0 1}$ & $\mathbf{0 . 0 2}$ \\
\hline
\end{tabular}

a Total available water content.

retention at lower suctions does not reveal any significant differences. The results of Queseras agree with the earlier results of Buytaert et al. (2002), who found that the wilting point ( $\mathrm{pF} 4.2$ ) of cultivated páramo soils is significantly lower than natural páramo soils.

A comparison of the saturated hydraulic conductivity, measured with the constant-head method, between Huagrauma and Soroche reveals a significant difference. Average saturated hydraulic conductivity in the cultivated Soroche is $17.5 \mathrm{~mm} \mathrm{~h}^{-1}$, compared with an average of $12.1 \mathrm{~mm} \mathrm{~h}^{-1}$ in Huagrauma (Table I).

An increase in the total available water for plants can be considered as an agricultural advantage, but the impact on the hydrology of the soils is less clear.

Buytaert et al. (2004) demonstrated that the cultivated Soroche catchment has a significantly lower water regulation capacity. This conclusion follows from the observation that, although Soroche is about $30 \%$ smaller than Huagrauma and the slopes are gentler, peak flows in Soroche are higher than in Huagrauma and the base flow is consistently lower.

The large storage capacity of the soils and the high saturated capacity in natural páramo soils, as well as the low intensity of precipitation in the páramo, result in a small contribution of surface runoff to the hydrological response. Therefore, the additional storage observed in cultivated soils probably does not add any additional value to the water regulation capacity. On the other hand, the increase in conductivity of the soils may accelerate the hydrological response, resulting in a faster decrease of the base flow. This process may be accelerated by the intensive artificial drainage that occurs in the cultivated catchments. Owing to the high water content, drainage is necessary in order to create favourable cropping conditions.

It is important to take into account that cultivation of the páramo region started recently and that longterm changes cannot yet be investigated. Organic matter content generally decreases when Andosols are cultivated (Higuchi and Kashiwaga, 1993; Moroizumi and Horino, 2002). Therefore, the observed available water increase is likely a temporary phenomenon, as ploughing and harrowing activities increase the total pore content of the soil. Over the longer term, the decrease in organic carbon will be an important factor. Better drainage and aeration will increase microbial activity and organic matter breakdown. Given the strong relationship between water retention and organic carbon content (Buytaert et al., 2002), the water retention capacity of the affected soils will most likely decrease. Additional investigation is necessary to assess the long-term effects of cultivation on the water retention capacity, and thus the behaviour of the total available water content for plants.

\section{Mualem-Van Genuchten formula}

The Mualem-Van Genuchten formula was tested on the water retention curve data for two reasons: (1) it is the most widely used, physically based model for water retention curves; (2) the development of a hydrological model is considered a valuable tool for the further understanding of hydrological processes in the páramo, and parametric mathematical descriptions are far easier to implement in simulation models than discontinuous point data. Some representative plots of the optimized Mualem-Van Genuchten model over the point data from Figure 4 are given in Figure 8. Large discrepancies between measured and plotted data can be observed, mostly due to a different shape of the curves. The continuous parametric description of Mualem and Van 
A

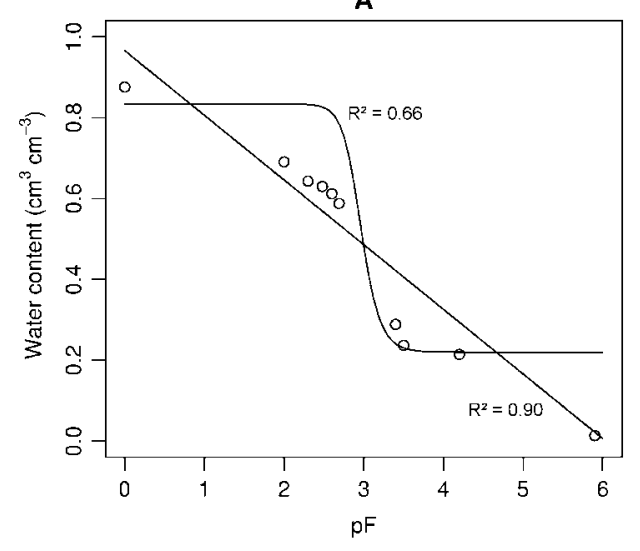

C

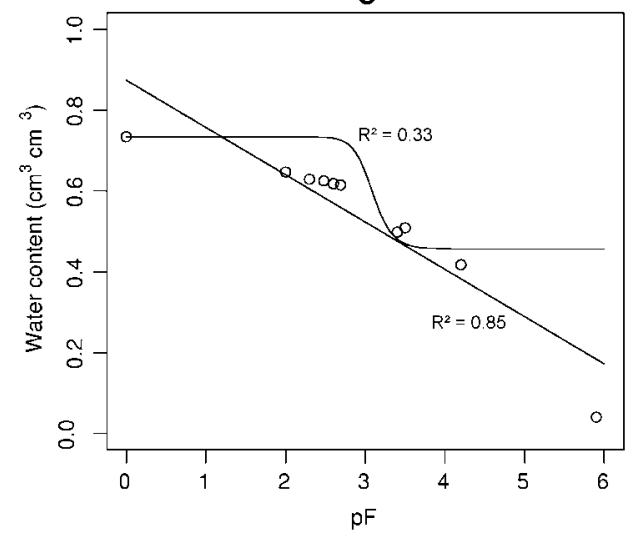

B

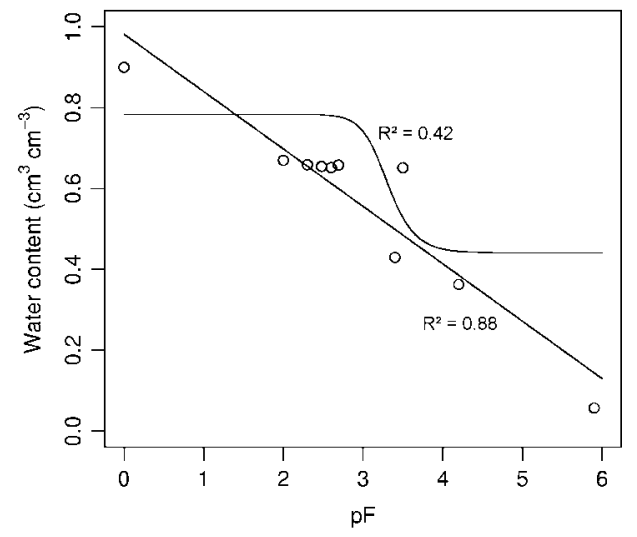

D

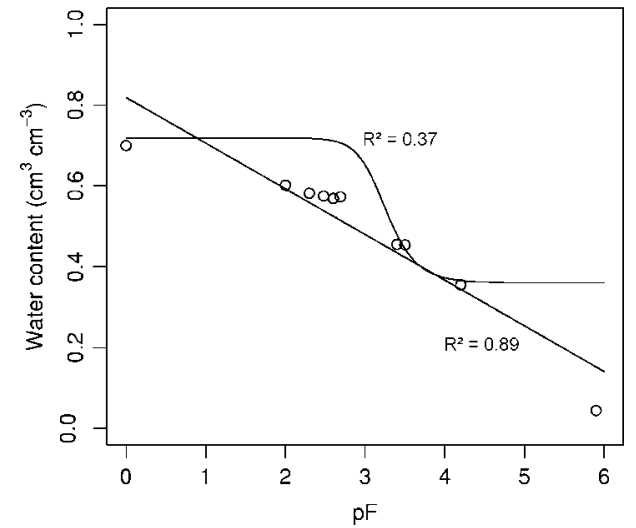

Figure 8. Modelling of the water retention curve of the Histic Andosols with both the Mualem-Van Genuchten model and a linear plot

Genuchten is based on a physical concept in which the soil is rather insensitive to air pressure up to the air entry point, where water is gradually released up to a residual water content coinciding more or less at the wilting point. Neither the air entry point nor the residual water content appear in the water retention curve of the páramo soils. Instead, probably due to the high variation in pore dimensions of the organometallic complexes, the Andosol $\mathrm{pF}$ curves have a more linear form, with a larger water release at low $\mathrm{pF}$, a less pronounced release between field capacity and wilting point, and a very high water retention at wilting point that is still far from the residual water content, as indicated by the air-dried water content. Therefore, the Mualem-Van Genuchten formula is not an adequate model for this soil type, and empirical fitting curves, such as flexible smooth functions, should be used (Prunty and Casey, 2002).

\section{CONCLUSIONS}

The Histic Andosols in the south Ecuadorian páramo region have a very high water retention capacity, ranging from up to $90 \mathrm{vol} \%$ at saturation point to $50 \mathrm{vol} \%$ at the wilting point. Their saturated hydraulic conductivity is high $\left(13.4 \mathrm{~mm} \mathrm{~h}^{-1}\right)$, but it decreases sharply in unsaturated conditions. The constant-head permeameter method, the inverted auger hole method and the tension infiltrometer method do not reveal significant differences in saturated hydraulic conductivity, and the measured range is comparable. Therefore, the REV for the páramo soils is rather small, and well represented by steel-ring samples of $100 \mathrm{~cm}^{3}$. 
Recent land-use changes have caused a significant decrease of the water retention capacity of the soils at wilting point, whereas retention at saturation point is less affected. These effects may increase the total available water for plants by up to $30 \%$. The saturated hydraulic conductivity increases by up to $31 \%$.

Owing to the lack of a uniform air-entry value and a diffuse residual water content, the physically based Mualem-Van Genuchten model is probably not the best method to use in future attempts to model the páramo hydrology.

\section{ACKNOWLEDGEMENTS}

We would like to thank Dr F. Cisneros, director of PROMAS, the programme for soil and water management of the Universidad de Cuenca, Ecuador, for the logistic help during the study, and Jaime Garrido, Pablo Borja and Vicente Iñiguez for their intensive help during the field work. Furthermore, we thank the Fund for Scientific Research Flanders, for funding W. Buytaert as a researcher.

\section{REFERENCES}

Basile A, De Mascellis R. 1999. Change of hydraulic properties and solute transport parameters in volcanic ash soils after drying. In Modelling of Transport Processes in Soils at Various Scales in Time and Space, Feyen J, Wiyo K (eds). Wageningen Academic Press, Wageningen: 267-275.

Bear J. 1975. Dynamics of Fluids in Porous Media. Elsevier: New York; 764

Bouma J. 1982. Use of soil survey data to select measurement techniques for hydraulic conductivity. Agricultural Water Management 6: $177-190$.

Brady NC, Weil RR. 1999. The Nature and Properties of Soils, 12th edition. Prentice-Hall: New Jersey; 879.

Buytaert W. 2004. The properties of the soils of the south Ecuadorian páramo and the impact of land use changes on their hydrology. Unpublished PhD thesis, Katholieke Universiteit Leuven.

Buytaert W, Deckers J, Dercon G, De Bièvre B, Poesen J, Govers G. 2002. The impact of land use changes on the hydrological properties of volcanic ash soils in south Ecuador. Soil Use and Management 18: 94-100.

Buytaert W, De Bièvre B, Wyseure G, Deckers J. 2004. The use of the linear reservoir concept to quantify the impact of changes in land use on the hydrology of catchments in the Andes. Hydrology and Earth System Sciences 8: 108-114.

Clothier BE, Kirkham MB, McLean JE. 1992. In situ measurement of the effective transport volume for solute moving through soil. Soil Science Society of America Journal 56: 733-736.

De Bièvre B. 2002. Water demand-supply and administrative management in medium sized irrigation schemes in the sierra of Ecuador. Unpublished PhD thesis, Katholieke Universiteit Leuven.

De Noni G, Prat C, Quantin P, Viennot M, Zebrowski C. 2000. Erosion et conservation, après récupération, des sols volcaniques indurés de l'equateur et du Mexique. Étude et Gestion des Sols 7: 25-36.

Dercon G. 2001. Tillage erosion assessment in the Austro Ecuatoriano. Unpublished PhD thesis, Katholieke Universiteit Leuven.

Dercon G, Bossuyt B, Bievre BD, Cisneros F, Deckers J. 1998. Zonificación Agroecologica del Austro Ecuatoriano. U Ediciones: Cuenca, Ecuador; 148.

Dorel M, Roger-Estrade J, Manichon H, Delvaux B. 2000. Porosity and soil water properties of Caribbean volcanic ash soils. Soil Use and Management 16: 133-140.

FAO/ISRIC/ISSS. 1998. World reference base for soil resources. World Soil Resources Report No. 84, FAO, Rome.

Golchin A, Baldock JA, Clarke P, Higashi T, Oades JM. 1997. The effects of vegetation and burning on the chemical composition of soil organic matter of a volcanic ash soil by C NMR spectroscopy. II. Density fractions. Geoderma 76: 175-192.

Hedberg O. 1992. Afroalpine vegetation compared to páramo: convergent adaptations and divergent differentiation. In Páramo: an Andean Ecosystem under Human Influence, Balslev H, Luteyn JL (eds). Academic Press: London; 15-30.

Higuchi T, Kashiwaga S. 1993. Changes of soil morphological characteristics and organic matter content after long-term cultivation in Andisols on the Musashino plateau, Japan. Soil Science and Plant Nutrition 39: 87-97.

Hofstede RGM. 1995. Effects of burning and grazing on a Colombian páramo ecosystem. Unpublished PhD thesis, Universiteit van Amsterdam.

Holden J, Burt TP. 2002. Laboratory experiments on drought and runoff in blanket peat. European Journal of Soil Science 53: 675-689.

Holden J, Burt TP. 2003. Hydraulic conductivity in upland blanket peat: measurement and variability. Hydrological Processes 17: $1227-1237$.

Holden J, Burt TP, Cox NJ. 2001. Macroporosity and infiltration in blanket peat: the implications of tension disc infiltrometer measurements. Hydrological Processes 15: 289-303.

Inoue M, Simunek J, Hopmans JW, Clausnitzer V. 1998. In situ estimation of soil hydraulic functions using a multistep soil-water extraction technique. Water Resources Research 34: 1035-1050.

Logsdon SD, Jaynes DB. 1993. Methodology for determining hydraulic conductivity with tension infiltrometers. Soil Science Society of America Journal 57: 1426-1413. 
Luteyn J. 1992. Páramo: an Andean ecosystem under human influence. In Páramos: Why Study Them?, Balslev HLJ (ed.). Academic Press: London; 1-14.

Medina G, Vásconez PM. 2001. Los páramos en el Ecuador. In Los páramos del Ecuador, Vásconez PM, Medina G, Hofstede R (eds). Proyecto Páramo Quito; 1-24.

Moroizumi T, Horino H. 2002. The effects of tillage on soil temperature and soil water. Soil Science 167: 548-559.

Mualem Y. 1976. A new model for predicting the hydraulic conductivity of unsaturated porous media. Water Resources Research 12: $513-522$.

Nanzyo M, Shoji S, Dahlgren R. 1993. Volcanic Ash Soils: Genesis, Properties and Utilisation. Developments in Soil Science No. 21. Elsevier: Amsterdam; 288.

Neall VE. 1985. Properties of Andisols important to pasture and horticulture. In Proceedings of the Sixth International Soil Classification Workshop, Chile and Ecuador. Part I: Papers, Beinroth FH, Luzio WL, Maldonado FP, Eswaran H (eds). Sociedad Chilena de la Ciencia del Suelo: Santiago, Chile; 109-189.

Piccolo A, Mbagwu JSC. 1999. Role of hydrophobic components of soil organic matter in soil aggregate stability. Soil Science Society of America Journal 63: 1801-1810.

Podwojewski P, Poulenard J, Zambrana T, Hofstede R. 2002. Overgrazing effects on vegetation cover and properties of volcanic ash soil in the páramo of Llangahua and La Esperanza (Tungurahua, Ecuador). Soil Use and Management 18: 45-55.

Poulenard J, Podwojewski P, Janeau JL, Collinet J. 2001. Runoff and soil erosion under rainfall simulation of andisols from the Ecuadorian páramo: effect of tillage and burning. Catena 45: 185-207.

Prunty L, Casey FXM. 2002. Soil water retention curve description using a flexible smooth function. Vadose Zone Journal 1: $179-185$.

Ritzema HP. 1994. Drainage Principles and Applications. ILRI: The Netherlands.

Rousseaux JM, Warkentin BP. 1976. Surface properties and forces holding water in allophane soils. Soil Science Society of America Journal 40: 446-451.

Shoji S, Fujiwara Y. 1984. Active aluminum and iron in the humus horizons of andosols from northeastern Japan: their forms, properties, and significance in clay weathering. Soil Science 137: 216-226.

Valat B, Jouany C, Riviere LM. 1991. Characterization of the wetting properties of air-dried peats and composts. Soil Science 152: $100-107$. Van Dam JC, Stricker JNM, Droogers P. 1992. Inverse method for determining soil hydraulic functions from one-step outflow experiments. Soil Science Society of America Journal 56: 1042-1050.

Van Genuchten MT. 1978. A closed-form equation for predicting the hydraulic properties of unsaturated soils. Soil Science Society of America Journal 44: 892-898.

Van Wambeke A. 1981. Calculated soil moisture and temperature regimes of South America; a compilation of climatic regimes calculated by using a mathematical model developed by F. Newhall. Soil Conservation Service, Ithaca, NY.

Wada K. 1985. The distinctive properties of Andosols. Advances in Soil Science 2: 174-223. 